\title{
LEGAL STATUS OF BANK GUARANTEE ON BEHALF OF THIRD PARTIES IN BANKRUPTCY PERSPECTIVE
}

\author{
Rahayu Hartini \\ Faculty of Law, University of Muhammadiyah Malang \\ Email: rahayuhartini@yahoo.co.id
}

\begin{abstract}
This study aimed to observe the legal status of the immovable that became a bank guarantee on behalf of third parties in the bankruptcy and whether the curator has the authority to insert objects that have been done Collateral guarantees which Foreclosed (hereinafter referred AYDA) prior to the bankruptcy decision boedel into bankruptcy.The method used is a normative research using three approaches: statute approach, conceptual approach, case approach, and analyzed "conten analysis". Based on the discussion of the results of research obtained the following conclusions: 1). The collateral property of a third party cannot be entered as boedel bankrupt debtor, as a third party guarantee is not a property of the Borrower; It is used as the basis of legal considerations (ratio decidendi) for the judges to decide the case of bankruptcy among Curator Albert Riyadi Suwono (applicant bankruptcy) with PT. Anglomas International Bank (AMIN BANK). 2). Curators do not have the authority to push objects of collateral that has been done AYDA prior to the bankruptcy decision into boedel bankrupt (pursuant to Article 56 Paragraph (1) the Bankruptcy Law that provides a period of suspension of execution rights guarantees security rights 90 (Ninety) days. In order not occur: legal norms are vague (vegen norm) and the conflict of norms and have an impact on the lack of legal certainty. Hence the need to revise the unprotected substrate of law No. 37 of 2004 on Bankruptcy and PKPU. Particularly with respect to Article 55 paragraph (1) and Article 56 paragraph (1).
\end{abstract}

Key words: legal status, bank guarantee, foreclosed properties, third party

\section{A. INTRODUCTION}

To prevent or reduce the risk of loss that may be experienced by the creditor, creditors (in this case the Bank usually) need to anticipate the possibility of the debtor can not pay its debts. The guarantee of bias in the form of immovable (mortgage) or moving objects (especially Fiducia). Understanding Security in general can be found in the Book of the Law of Civil Law (hereinafter referred to as the Civil Code), in particular in Article 1131 of the Civil Code, namely any material someone either moving or not moving, either existing or new will be there later to become dependent on any individual engagement. However, guaranteed in general still felt inadequate by the lender so the lender is often granted by th special guarantee which may be collateral material and individual guarantees (borgtocht). At the material guarantee, debtor / debtor warrant objects to the lender, as collateral for loans borrowed by the debtors (M. Yahya Harahap, Bandung, 1982: 315). 
If the debtor does not repay its debts at maturity then the creditor can demand the execution of the objects that have been pledged by the debtor to repay their debts. While the guarantees of individual or borgtocht The guarantees given by the debtor is not a thing but a statement by a third party (the surety / guarantor) who do not have the benefit of any kind to the debtor and the creditor, that the debtor can be trusted and carried out the obligations of the agreement; with the provision that if the debtor does not perform its obligations then the third party that is willing to carry out the obligations of the debtor (M. Yahya Harahap, Bandung, 1982: 315).

The guarantee of individual/borgtocht intended that the creditor can demand the guarantor to pay the debts of the debtor if the debtor negligent or unable to pay its debts. In practice, it also often found their goods with a guarantee on behalf of another person / third party other than the debtor itself. It could be because it is materially and formally goods such guarantees the private property of third parties / do not belong to the debtor or may also formally still listed on someone's behalf even though perhaps materril are the property of the debtor that has not been behind the name of the name of the debtor concerned. How is good as the Guarantee of Bank on behalf of another person / third party and the debtor goes to bankrupt? Will the collateral can be drawn into the boedel bankruptcy (bankruptcy estate) .

\section{B. PROBLEM STATEMENT}

Based on the background that the author has problems as the following i.e:

1. What is the legal status of the immovable goods that became a bank guarantee on behalf of third parties in the bankruptcy?

2. Does the curator has the authority to insert objects that have been made AYDA collateral (foreclosed properties) before the bankruptcy decision boedel into bankruptcy? And what the legal consequences of bankruptcy?

\section{RESEARCH METHOD}

This type of research is a normative research which the philosophy of norms related to the subject matter studied, which is the norm in the field of Bankruptcy Law and Banking Law. The approach will be analyzed by the approach of the shrimp-law (statute approach), the conceptual approach (conceptual approach), and the approach of the case (case approach) (Peter Mahmud Marzuki, Jakarta: 93-95).

Whereas primary and secondary legal materials that have been collected through the inventory, then grouped and studied approach to the law (statute approach) to acquire basic 
knowledge of the legal material. The materials are prescriptive law. As a prescriptive science, the science of law study law purposes, the values of justice, the validity of the rule of law, legal concepts and legal norms. As an applied science of jurisprudence sets the standard procedure, the provisions of the guidelines in implementing the rule of law. Prescriptive nature is something substantial in the science of law (Peter Mahmud Marzuki, Jakarta: 22). After that, the law has classified material then analyzed, examined and studied by comparing with the doctrine, theory and legal principles suggested by experts, based on reasoning or logic in legal arguments. The analysis was conducted to find out the truth

\section{RESEARCH RESULTS AND DISCUSSION}

\section{Legal Status Of Objects Stationary (Bank Guarantee on Behalf of Third Parties In Bankruptcy)}

The bankruptcy institute is a legal institution that plays an important role, as the realization of two important articles in the Civil Code Article 1131 of the Civil Code and Article 1132 of the Civil Code on the responsibilities of debtor's debts (Rahayu Hartini, 2014: 99). Article 1131 of the Civil Code states that all lebendaan the debt, whether moving or not moving, either existing or new will exist in the future, be dependent on any engagement individually. Article 1132 of the Civil Code, that the material becomes collateral who lend to him, the sales revenue of objects were divided according to the balance, ie, according to the size of the individual receivable unless there are reasons legitimate to take precedence. The two articles mentioned give an assurance to the lender that the debtor's obligations will still be met / repaid with a guarantee of riches debtor either already exist or are still going to exist in the future. In other words, that bankruptcy is a mass execution determined by the judge's decision, applicable immediately, by confiscating on all the property of people declared bankrupt, both existing at the time of the declaration of bankruptcy, or obtained during the bankruptcy takes place, for the benefit of all creditors, who performed under the supervision of the authorities (Sutantio, 1996, Jakarta: 85).

According to Law Number 37 of 2004 on Bankruptcy and Suspension of Payment (hereinafter Labor Law) therein arranged on the position of rights holders of mortgage creditor if the debtor goes to bankrupt, Beside that in Law Number 4 of 1996 on Mortgage (hereinafter referred Mortgage Law) set of laws on the same matter. In this case there is actually a conflict between the norms of the Law Number 37 of 2004 on Bankruptcy and Suspension of Payment by Law Number 4 of 1996 on Encumbrance of the position of creditors holders of security rights if the debtor bankrupt. 
On this subject, it can be found in Article 21 of the Mortgage Law, which states that if the lender Mortgage declared bankruptcy, creditors Mortgage holders authorized to do whatever is gained by Mortgage Law (Soerjono Soekanto and Mamoedji, 1985, Jakarta: 70). Which means that the creditor notch security rights holders remain guaranteed, even though the debtor declared bankrupt by the court. In this case, according to Adrian Sutedi, object security rights are not included as assets (boedel) bankruptcy, so that creditors rights holders and dependents as a secure creditor can execute Encumbrance as no bankruptcy (Adrian Sutedi, 2012, Jakarta: 169).

But the presence of Article 56 and Article 59 of Bankruptcy Act led to a conflict of norms, as mentioned payment of debts of the debtor to the creditor holders of security rights take precedence, the right execution creditor holders of Mortgage to the Mortgage that is in control of the lender suspended for a maximum period of 90 days, thus the position of creditors holders of security rights to the object encumbrance to be weak, because of creditor rights holders has been reduced encumbrance or restricted.

Furthermore, related to the legal issue in this study to focus on the problem of the immovable property of third parties as collateral debt, and is concerned sentenced to bankruptcy are as follows:

Whereas pursuant to Article 59 Paragraph (2) of Law Number 37 of 2004 on Bankruptcy regarding Third Party collateral pledged and by Curator entered into the treasures boedel bankruptcy, should focus on the entry into force of the legal principle: The principle of Lex Specialist derogat legi generalist. The Law on Mortgage (HT Act) is a lex specialis of the Bankruptcy in this case.

Therefore, if there is collateral pledged, the reference is the Mortgage and institutions that are the guarantors are separatists creditors when referring to article 55 of Law Number 37 of 2004 on Bankruptcy, then the guarantee institution should be regarded as if nothing happened bankruptcy.

Meanwhile, in line with Article 59 Paragraph (2) of Law Number 37 of 2004 on Bankruptcy, in case there are two collateral certificate, the first is the certificate belongs to the Borrower and the second is the certificate belonging to third parties that pledged to the Bank Guarantor then inserted by the Receiver into the treasures boedel bankruptcy, the certificate of a third party it can not just put in boedel bankruptcy, but should be seen right pad once used as collateral. "If the certificate on behalf of another person then it can not be included as boedel bankrupt debtor, as a third party guarantee does not belong to the Borrower"; (This is the opinion of an expert witness: Prof. Dr. Rahayu Hartini, SH, M. Hum, 
the Bankruptcy Decision 18 / Plw.Pailit / 2013 / PN.Niaga SBY jo No. 06 / Bankrupt / 2011 / PN. Niaga. SBY).

In Article 59 paragraph (2) of Law Number 37 of 2004 on Bankruptcy associated with Article 1 Paragraph (1), Article 55 and Article 21 of Law Number 37 of 2004 on Bankruptcy, then the third-party certificate will be back to basics ownership / owner and the certificate can not necessarily be included by the Receiver into bankruptcy because boedel treasure should be based on the bottom right of ownership. It is based on the soul of the Bankruptcy Act in order to protect the interests of creditors and interests of debtors, but for the sake of legal certainty banking, third party goods into a security interest are not including the bankruptcy estate, as a third party instead of the debtor bankrupt.

The judges who hear the case between Albert Riyadi Suwono bankruptcy (curator) against Pt. Anglomas International Bank (Amin Bank) in the District Court of Commerce, Surabaya in 2013 also agrees with the expert witness, Prof. Dr. Hartini Rahayu, SH, M. Hum., That the collateral property of a third party can not be entered as boedel bankrupt debtor, as a third party guarantee does not belong to the Debtor (see Insolvency Decision 18 / Plw.Pailit / 2013 SBY /PN.Niaga jo No. 06 / Bankrupt / 2011 / PN. Niaga. SBY).

Based on the description of the analysis can be said that the collateral property of a third party can not be taken as boedel bankrupt debtor, as a third party guarantee is not a property of the Borrower; It is used as the basis of legal considerations (ratio decidendi) for the judges to decide the case of bankruptcy among Curator Albert Riyadi Suwono (applicant bankruptcy) with PT. Anglomas International Bank (Amin Bank).

\section{Foreclosed Properties Prior existence Boedel Into Bankruptcy Decision.}

\section{a. Foreclosed (AYDA)}

The provisions regarding the collateral Foreclosed stipulated in Bank Indonesia Regulation Number 7/2 / PBI / 2005 Concerning Asset Quality Rating for Commercial Banks, in particular Part 2, starting Articles 37-39.

The meaning of Foreclosed hereinafter referred to as foreclosed assets are assets acquired by Bank, both through auctions and non auction based on voluntary transfer by the debtor or by the power to sell outside of the auction of the collateral where the debtor fails to meet its obligations to commercial banks (Article 1 point 15). 
Article 37 states that: (1) The Bank shall make efforts to resolve the AYDA. (2) Banks are required to document AYDA settlement efforts as referred to in paragraph (1).

Article 39 states that, for foreclosed assets that have been made settlement efforts as referred to in Article 37, is set to have 4 quality maca, namely:

a. Current, if foreclosed assets held for up to 1 (one) year;

b. Substandard, if foreclosed assets held for more than 1 (one) year to 3 (three) years;

c. Doubtful, if the foreclosed assets held for more than 3 (three) years to 5 (five) years;

d. Loss, if foreclosed assets held for more than five (5) years.

As for foreclosed assets that are not carried settlement efforts as referred to in Article 37 , is set to have one level below the provisions referred to in paragraph (1).

Furthermore, in Article 38, states that:

(1) The Bank shall reevaluate the AYDA to establish realizable value of repossessed assets.

(2) The re-evaluation of the foreclosed assets referred to in paragraph (1) shall be conducted at the time of the takeover of the collateral.

(3) .Arrears interest solved by AYDA not be recognized as income until their realization

(4) .Determination net realizable value as referred to in paragraph (1) shall be performed by an independent appraiser, to foreclosed assets with a value of $\operatorname{Rp~5,000,000,000.00~(five~}$ billion rupiah) or more.

(5) The net realizable value can be performed by internal appraiser Bank, to the value of foreclosed assets of less than Rp 5,000,000,000.00 (five billion rupiah).

(6) Banks are required to use the lowest value when there are multiple values of the independent assessor referred to in paragraph (4) or the internal appraiser referred to in paragraph (5).

(7) independent .Evaluator referred to in paragraph (4) an appraisal company that:

a. not a Related Party with the Bank;

b. not a debtor Borrower Group with the Bank;

c. conducting the assessment is based on the code of ethics and the rules set by the competent institution;

d. using a valuation method based on professional standards assessment issued by the competent institution;

e. has a business license from the competent institution to operate as an appraisal company;

f. recorded as a member of an association recognized by the competent institution. 


\section{b. Curator in Bankruptcy}

The provisions concerning the curator stipulated in Law Number 37 of 2007 on Bankruptcy, especially for Paragraph 2 (Article 69 -78).

Article 69 states that the task of curator is:

1) management and / or settlement bankruptcy assets.

2) .in carrying out their duties, Curator:

a. not required to obtain approval from or give prior notification to the debtor or one of its organs Debtors, though in a state outside of bankruptcy approval or notification as required;

b. may apply for loans from third parties, only in order to increase the value of the bankruptcy estate.

3). When doing a loan from a third party, Curator need to overload the bankruptcy estate by pledge, fiduciary, encumbrance, mortgage, or other material rights of the collateral on the loan must first obtain the approval of the Supervisory Judge.

4). Imposition of the bankruptcy estate by pledge, fiduciary, encumbrance, mortgage or collateral rights on other material referred to in paragraph (3), can only be done on the part of the bankruptcy estate that has not been used as security for a debt.

5). To meet in the Court proceedings, the Receiver must first obtain permission from the Supervisory Judge, unless the dispute involves matching receivable or in the case referred to in Article 36, Article 38, Article 39 and Article 59 paragraph (3).

\section{c. Curators do not have the authority to insert objects that have been made AYDA} collateral (foreclosed properties) before the bankruptcy decision boedel into bankruptcy

As previously explained that the duties and authority of the main curator is doing the maintenance and/or settlement of bankruptcy property (Article 69 of the Labor Law).

The verdict passed by the court declaration of bankruptcy does not lead to the extinction of the security rights. Creditor rights holders remain dependents have the right to execute their own preferences will object mortgages mastered. But in execution of the security rights should remain subject to the Bankruptcy Act which provides a period of suspension of execution rights guarantees security rights 90 (ninety) days after the bankruptcy decision made by the court in accordance with the provisions of Article 56 paragraph (1) of the Bankruptcy. It also regulates the provisions concerning the execution time limit mortgages restricted to only two (2) months. Meanwhile, according to Article 55 Paragraph (1) Labor Law stated that regarding the provisions referred to in Article 56, Article 57, and Article 58, 
each Creditor pawnee, fiduciary, encumbrance, mortgage, or the right collateral for other materialistic, can execute their rights as if nothing happened bankruptcy. Mortgage object holder having preferential rights, namely the right to precedence in debt repayment over the object encumbrance (Adrian Sutedi, 2012, Jakarta: 171).

\section{E. CLOSING}

There are some conclusions based on the results of the discussion of this study are as follows:

\section{Conslusion}

a. Goods belonging to a third party guarantee can not be taken as boedel bankrupt debtor, as a third party guarantee is not a property of the Borrower; It is used as the basis of legal considerations (ratio decidendi) for the judges to decide the case of bankruptcy among Curator Albert Riyadi Suwono (applicant bankruptcy) and PT. Anglomas International Bank (AMIN BANK).

b. Receivers have no authority to insert objects that have been made AYDA collateral (foreclosed properties) before the bankruptcy decision boedel into bankruptcy (under Article 56 Paragraph (1) the Bankruptcy Law that provides a period of suspension of execution rights guarantee the security rights at the latest 90 (Ninety) days.

\section{Suggestions}

To avoid legal norms are vague (vegen norm), there is a conflict of norms and have an impact on the lack of legal certainty. Therefore it is necessary to apply their revision of the unprotected substrate of Law Number 37 of 2004 on the Bankruptcy. Particularly with respecting Article 55 paragraph (1) and Article 56 paragraph (1).

\section{BIBLIOGRAPHY:}

AdrianSutedi,2012,HukumHakTanggungan (Law on The Mortgage Right), Jakarta: SinarGrafika.

M. Yahya Harahap, 1982. Segi-Segi Hukum Perjanjian (Aspects of Contract Law), Bandung: Alumni.

Peter Mahmud Marzuki, Penelitian Hukum (Research Methods), Kencana, Jakarta: Prenada Media Group.

Rahayu Hartini. 2006. Hukum Kepailitan (Bancruptcy Law), Edisi Revisi, Malang: UMM Press.

Soerjono SoekantodanMamoedji,1985,Penelitian Hukum Normatif (Normative Research 
Methods) ,Radjawali,Jakarta.

Sutantio, Kapita Selekta Hukum ekonomi dan Perbankan (Kapita Selekta: Economic and Banking Law), seri varia Yustisia, Jakarta, 1996.

Rahayu Hartini's Thought on the Bankruptcy Verdict Number 18/Plw.Pailit/2013/PN.Niaga Sby jo No. 06/Pailit/2011/PN. Niaga. Sby).

\section{Regulation:}

Law Number 37 of 2004 on The Bankruptcy

Law Number 4 of 1996 on The Mortgage.

Law Number 10 of 1998 on The Banking Law.

\section{Verdict:}

Verdict of the Commerce District Court of Surabaya, No. 18/ Plw. Pailit/2013/PN Niaga Sby jo. Put No. 06/Pailit/2011/PN. Niaga Sby. 